\title{
Comparative Constitutionalism in the Southeast Asia-Pacific Region: Is a Unifying Telos Possible?*
}

\author{
Vanitha Sundra-Karean \\ Senior Lecturer (Law), School of Law and Justice \\ University of Southern Queensland, Springfield Campus, Australia \\ Email: Vanitha.Sundra-Karean@usq.edu.au
}

\section{INTRODUCTION}

What is 'constitutionalism' and is a comparative study useful? 'Constitutionalism' may be described as a principle or ideal in constitutional and administrative law, which prescribes limitations on state power.

Why are limitations on state power important? The short answer to that question is as stated by Lord Acton that 'power tends to corrupt and absolute power corrupts absolutely'. However, it is not just corruption or dishonesty of the financial kind that is to be eschewed. Any abuse of power that is ultra vires its purpose, should be checked and controlled. What then are the desired, or prescribed limitations on power, and does it matter if these limitations are couched in Western terms, as the prevalent practice seems to be? Or should they be couched along Asian or Islander norms for the countries situated in those regions? Does it really matter? Should not the focus be on discovering and highlighting unifying themes, whilst paving the way for a considered sharing of values?

What is comparative law and why is it important? Comparative law seeks to inform particular jurisdictions under study, how legal systems within other jurisdictions operate, the constitutional norms that are employed in those jurisdictions, and whether the methods used to achieve constitutional and administrative law outcomes arose out of legal transplants, or were autochthonous / home-grown. Such comparative study fosters contextual interpretation of constitutional problems, and allows cross-fertilisation of constitutional ideas amongst nations and jurisdictions either through formal legal transplants, or through judicial influence. Even with formal legal transplants, the interpretive role is cardinal.

The scope of this conference topic is broad, covering nations in the Southeast Asia- Pacific region. I will limit my analysis to Malaysia, with some comparative reflections on Australia.

\section{THE CASE OF MALAYSIA}

Colonial Malaya was an amalgam of cultures, traditions and values representing the Malay, Chinese, Indian and Sri Lankan races, within a British backdrop. The various facets of the legal system that unfolded contained spontaneous reflections of these forces, and were therefore influenced by the underlying philosophies of the cultures that made Malaya. These underlying philosophies, sometimes distinct, and often culturally fused, were mainly rooted in Islam, Hinduism, Confucianism, Buddhism and Christianity. The Adat, or Malay customary law, with its Hindu influence, serves as a prime example of such confluence. It may be readily observed that 'atonement' is a value underpinning these religions, whilst the parallel value of 'accountability' underscores the rule of law principle, which aims to uphold constitutionalism. Such parallels between religious philosophy and cultural values on the one hand, and principles upholding constitutionalism on the other, are not difficult to draw. There may well be a unifying telos amongst diverse constitutions after all.

Although the Federal Constitution of Malaysia contains a bill of rights embodying the Western articulation of civil and political rights, and many of these provisions are in pari materia with the bill of rights provisions within the Indian Constitution, one only needs to look at the Indian Independence movement and Mahatma Gandhi's Swaraj ${ }^{1}$ strategy to appreciate that the freedoms of expression, assembly and movement, were home-grown in its South Asian variant. John Lock's natural law theory, which formed the bedrock of Western human rights theories, was in existence in different iterations in India through the Hindu classical legal concepts of $S_{r u t i}{ }^{2}$ and Smrti. ${ }^{3}$

Although Western liberal constitutional theories and concepts (rule of law, separation of powers, entrenched bills of rights, constitutional supremacy; parliamentary democracy) were introduced into the Malaysian legal system, these Western theories were often applied and interpreted in the prevailing cultural context. The landmark event which necessitated such an approach was the rejection, by the Malay Sultans, ${ }^{4}$ of the Malayan Union in 1946, which sought to centralise, and consolidate British power. ${ }^{5}$ That strong rejection set the pace for greater consultation and

\footnotetext{
* Draft-Work-in-Progress, please kindly do not cite.

Self-rule based on communal interests.

The four Vedas (Rig Veda, Sama Veda, Yajur Veda and Atharva Veda) and Upanishads revealed to ancient sages and passed on to be interpreted without specific rules or codes. These are primary sources. Collections of customary law functioning as illustrations and interpretations of the Sruti. These are therefore, changing norms. The Malay Sultans were the local Malay Rulers

Rais Yatim, 'The Road to Merdeka', in Andrew Harding and H.P. Lee (eds), Constitutional Landmarks in Malaysia - The First 50 Years 1957-2007, 1-24.
} 
local input into constitutional design. What followed was the Federation of Malaya Agreement 1948, which provided a template for self-rule through the recognition of the sovereignty of the Malay Sultans, and provisions safeguarding the special interests of the Malays and natives, alongside the legitimate interests of the other communities. ${ }^{6}$

A negative corollary of the rejection of the Malayan Union, was the ignition of Malay nationalism, and the formation of the United Malays National Organisation (UMNO) in the same year. The Chinese then followed with the formation of the Malayan Chinese Association (MCA) in 1949, which had as its main focus, efforts to distance itself from communist ideology, the Communist Party of Malaya, and safeguard the community's interests in the market economy. The Indians followed suit in 1951 by forming the Malayan Indian Congress (MIC), which had as its aim, the protection of Indian workers in rubber estates, and strengthening trade unionism. ${ }^{7}$ UMNO, MCA and MIC - all race-based political parties, went on to form the coalition Alliance Party, forming government, and which evolved into the present day Barisan Nasional (National Front) party, now in opposition for the first time in Malaysia.

The Federation of Malaya Agreement 1948, which was passed to appease the local Malays in the Malayan Union aftermath, envisaged the march to Independence in nine years. This was constructed through the setting up of the Reid Commission, who were tasked to draft a new Constitution for the new federation. Whilst the Reid Commission was made-up of eminent Scottish, British, Australian, Indian and Pakistani jurists, they consciously engaged in extensive consultations with local leaders as was their terms of reference. Such consultations resulted in the consultative narratives being entrenched in the resulting new Constitution. As such, the Federal Constitution of Malaysia is clearly autochthonous, as there was significant local input at its inception, and continually, through contextual constitutional interpretation. Thus was the 'prevailing cultural context' of early Malaysian constitutionalism, wherein a system of parliamentary democracy founded upon a social contract built upon a bill of rights, existed alongside a system of personal Syariah law upheld by the framework of constitutional monarchy. Most importantly, an independent judiciary, by and large, acted without fear or favour. ${ }^{8}$ This 'prevailing cultural context' however, was hijacked by authoritarian politicians keen to contrive constitutionalism along personal agendas, or within rentseeking interest groups keen to consolidate political power. This was seen over the years through the enforcement of broad sedition and other laws designed to curb freedom of speech, and in recent times in relation to the sensationalised

\footnotetext{
Section 19(1)(d) Federation of Malaya Agreement 1948

It is important to note that whilst the Chinese were effectively united as a race interested in promoting the economic interests of the Chinese community in the face of Malay special privileges, and in progressing the free market philosophy, the MIC was premised upon the class struggle of Indian labourers, thus accentuating the negative aspects of the Hindu caste system.

8 Pengarah Tanah dan Galian, Wilayah Perseketuan v Sri Lempah Enterprise Sdn Bhd [1979] 1 MLJ 135; Minister of Home Affairs $v$ Jamaludin bin Othman [1989] 1 MLJ 369; JP Berthelsen $v$ Director General of Immigration, Malaysia (1987) 1 MLJ 134; Pihak Berkuasa Negeri Sabah v Sugumar Balakrishnan (2002) 4 CLJ 105.
}

sodomy trials involving a past deputy prime minister, together with restrictions on freedom of assembly, expression and personal liberty. ${ }^{9}$ The ongoing consolidation of political power and systematic dismantling of institutional integrity culminated in the recent $1 \mathrm{MDB}$ scandal, which gloriously unseated a political party that had been in power for 61 years since Independence in Malaysia. Finally, Malaysians said 'no' in one united race-neutral voice! The unintended consequences of race-based politics, which initially was a spontaneous immediate reaction to the Malayan Union for pragmatic reasons, and not consciously crafted as a long-term political strategy, were configured to unfold with deft political manipulation in later years, only to face complete derailment 61 years later in the recent election tsunami of May 2018. Most Malaysians are hopeful that race-based politics will not rear its ugly head again, as for the very first time in Malaysian history, Malaysia is being governed by a coalition of political parties that are not aligned along the lines of race. A fresh beginning and a new Malaysia indeed, but will this reformation last? It is this author's view that an independent judiciary, together with changing societal values that are consonant with the rule of law ideal, harness social harmony, which in turn facilitates constitutionalism.

Quite often, in relation to race relations and communal politics, political leaders have been instrumental in driving wedges between the various ethnic groups in order to court political capital, instead of advocating harmony, integration and acceptance. The broad-brush approach taken by the outgoing Barisan Nasional executive in the past, in order to harness its own political power, did not discriminate between political freedoms and personal freedoms. Islam, being the most viable source of political power in modern Malaysia, was used indiscriminately by various moral police sanctioned by the executive, to shred the multi-religious and multi-racial harmonious social contract that was delicately woven at Independence. Apart from the controversial religious conversion and child custody cases of the recent past, which has seen a refreshing change in favour of freedom of religion in recent times,${ }^{10}$ a weak minority group that has been targeted in Malaysia is the transgender community. An analysis of the cases involving the transgender community in Malaysia reveals the importance of changing societal attitudes and values in realising the rule of law ideal.

\footnotetext{
9 See Andrew Harding, Law, Government and the Constitution in Malaysia (LexisNexis 1996) for an in-depth study of the constitutional arrangements and defining events in Malaysia's constitutional history.

10 Lina Joy v Majlis Agama Islam Wilayah Persekutuan [2007] 4 MLJ 585; Indira Gandhi Mutho v Pengarah Jabatan Agama Islam Perak [2018] 3 CLJ 145. The recent landmark Indira Gandhi case has restored parental rights in child conversion cases to both parents.
} 


\section{TRANSGENDER INJUSTICE IN MALAYSIA: A CASE STUDY HIGHLIGHTING THE VALUE OF COMPARATIVE METHODOLOGY AND THE IMPORTANCE OF CONTEXTUAL CONSTITUTIONAL INTERPRETATION}

Historical accounts show that the transgender community was traditionally and culturally accepted by Malay royalty and played various roles in early Malay society. ${ }^{11}$ This followed the treatment and acceptance of transgender individuals in Hinduism within Smriti, ${ }^{12}$ wherein as a minority, they were a protected group. However, since the mid-1980s in Malaysia, which witnessed the start of fervent Islamisation and moral policing, transgender individuals have been subjected to oppressive treatment, often meted out by religious authorities and legal enforcement agencies. ${ }^{13}$ Whilst there has been some judicial movement in restoring liberties in the context of freedom of religion, ${ }^{14}$ the same cannot be said of recognising the personal liberties of the transgender community in Malaysia. It is hoped that with steps towards the restoration of the rule of law in Malaysia after GE14, ${ }^{15}$ a reinvigorated judiciary will be more vigilant in safeguarding minority rights by adopting a purposive interpretation of human rights provisions in the Federal Constitution.

In a 2005 High Court decision regarding a postoperative male-to-female transsexual, the court took a liberal approach and stated that ' $[\mathrm{t}]$ he plaintiff felt like a woman, lived as a woman, behaved like (sic) a woman, had a physical body of a woman and most importantly, had the psychological thinking of a woman. When determination of a person's sex is based on medical evidence, the courts should play their part and grant relief according to justice.' 16

However, this changed in 2013 in Kristie Chan v.

Ketua Pengarah Jabatan Pendaftaran Negara, which involved a post-operative male-to-female seeking a declaration to change gender status in their identity card. The Court of Appeal dismissed the appeal and stated that, ' $[\mathrm{t}]$ here was no evidence, medical, and psychiatric, from experts in Malaysia as to what was gender, what made a person a male or female or whether sex reassignment surgery changes a person's gender to warrant a change of the gender description in that person's identity card.' ${ }^{17}$

In 2015, in the case of Fau En Ji v. Ketua Pengarah Jabatan Pendaftaran Negara, ${ }^{18}$ the High Court rejected the plaintiff's application for judicial review seeking to change the gender status and name on their identity card. The plaintiff was a post-operative female-to-male transsexual,

11 Farish A. Noor, What Your Teacher Didn't Tell You : The Annexe Lectures (Matahari Books, 4th ed. ed, 2010).

12 Note 3 above.

13 Julian Lee, Policing Sexuality : Sex, Society, and the State (Zed Books, 2011).

14 Indira Gandhi Mutho v Pengarah Jabatan Agama Islam Perak [2018] 3 CLJ 145.

15 The May $201814^{\text {th }}$ Malaysian General Election.

$16 J-G$ v. Pengarah Jabatan Pendaftaran Negara [2005] 4 CLJ 710, 711

17 [2013] 4 CLJ 627, 628.

18 [2015]1 CLJ 803 who had undergone medical surgery in Thailand. The court stated that 'gender is a multifaceted question... [i]t does not involve the desire of the applicant alone, but involves consideration of chromosomal, gonodal, genital and psychological factors.' ${ }^{19}$ The court not only failed to recognize the plaintiff's self-ascribed gender identity, but reinforced the gender status as recorded in the individual's birth certificate.

However, more recently in the case of Tan Pooi Yee v. Ketua Pengarah Jabatan Pendaftaran Negara, ${ }^{20}$ the High Court held that the plaintiff, a post-operative female-to-male transsexual was 'physically, anatomically and psychologically a male', and hence the law should declare the plaintiff as being male. ${ }^{21}$ The court took into consideration expert medical evidence which deposed that 'gender also depends on other factors, such as one's lifestyle and psychological condition. In the case of the plaintiff, the plaintiff's lifestyle, values, conduct and behaviour are consistent with the social and cultural norms of a male'. The court was influenced by the approach taken by the Family Court in Australia in Attorney-General for the Commonwealth $v$ "Kevin \& Jennifer" 22 where the Court emphasized the importance of abandoning the chromosomal factor and highlighting the imperative need to view the matter from the psychological perspective.

Whilst the outcome and reasoning in Tan above has been heralded as providing a beacon of hope to the weak transgender community, in empowering them as citizens to claim the protection of human rights provisions, a conflict of laws seems to stand in the way of transgender individuals who also identify as Muslims.

In 2011, an alliance of cause lawyers and the transgender community filed a test case known as the Mak Nyah case in the High Court in order to challenge the constitutionality of Section 66 of the Syariah Criminal Enactment 1992, Negeri Sembilan, which provides:

\footnotetext{
'any male person, who in any public place wears a woman (sic) attire and poses as a woman, shall be guilty of an offence and shall be liable on conviction to a fine not exceeding one thousand ringgit or to imprisonment for a term not exceeding six months or to both.'
}

Four Muslim males who were transgender, made an application for judicial review and sought a declaration that Section 66 was inconsistent with several provisions in the Federal Constitution of Malaysia that guaranteed fundamental constitutional rights and liberties. These rights and liberties included article 5(1) which grants the right to life and personal liberty, article 8(1) which grants the right to equality before the law and equal protection of the law, article $8(2)$ which grants the right to non-discrimination on the basis of gender, article 9(2) which secures the freedom of movement, and article 10(1)(a) which grants the freedom of speech and expression.

$$
\begin{aligned}
& \text { [2015] } 1 \text { CLJ 803, } 804 . \\
& \text { [2016] } 8 \text { CLJ 427. } \\
& \text { [2016] } 8 \text { CLJ 427, } 451 . \\
& \text { [2003] FamCA 94, } 295 .
\end{aligned}
$$


Apart from the constitutional rights argument, the applicants also relied on the gender identity argument on the basis that transgender individuals were men with a medical or psychological condition known as 'gender identity disorder', ${ }^{23}$ and that they should be legally excluded from the definition of 'any male person' in Section 66. Expert medical evidence was adduced. Whilst the High Court did not find in favour of the applicants, the Court of Appeal agreed with the gender identity argument and iterated that:

'...gender identity disorder is an attribute of the appellants' nature that they did not choose and cannot change; and that much harm would be caused to them should they be punished for merely exhibiting a manifestation of gender identity disorder i.e. cross-dressing., 24

The court further stated that Section 66 was unconstitutional as it had impeded the constitutional rights to life and liberty, freedom of expression and the freedom of movement.

Unfortunately, the Federal Court overturned the Court of Appeal decision. The Federal Court found that the transgender claimants had procedurally erred in seeking a High Court declaration to challenge the constitutionality of Section 66, a Syariah provision. ${ }^{25}$ The Federal Court stated:

'The issue here was not whether the appellants were prejudiced by the mode of action undertaken by the respondents. The case raised a larger issue. It was about the jurisdiction of the courts. The fundamental question was whether the validity or constitutionality of section 66 could be challenged in the High Court by way of a collateral attack in a judicial review proceeding. ${ }^{26}$

Whilst the Mak Nyah outcome has been disappointing from a constitutionalism perspective, the case has certainly set the tone for a consideration of the nature of the Federal Constitution of Malaysia - is it theocratic or secular? That question must necessarily be the most important legal question for the new Malaysia.

\section{CONCLUSION}

Is a 'unifying telos' achievable in the Southeast Asia-Pacific region? Yes, so long as the 'law' paradigm that is used to achieve constitutionalism reflects the rule of law ideal along natural law philosophy, and not merely positive law in the Kelsenian sense of the concept of law.

A unifying theme necessary to achieve that unifying telos would be the need to respect minority interests, and to find a space for minority interests to be nurtured within the constitutional fabric of any given nation. An example from Australia is the recent referendum on marriage equality - the majority has spoken, but the minority view that opposes same-sex marriage should also be respected, and be allowed to be expressed through the necessary legal protections. In

3 Gender dysphoria.

24 State of Negeri Sembilan \& Ors v. Muhammad Juzaili Mohd Khamis \& Ors [2015] 1 CLJ 954, 964.

25 State of Negeri Sembilan \& Ors v. Muhammad Juzaili Mohd Khamis \& Ors [2015] 8 CLJ 975.

26 [2015] 8 CLJ 975, 976. that regard, the time has certainly come to revisit the constitutionally entrenched bill of rights question, for Australia. 